DE DE GRUYTER OPEN
Research Article

(c) 2018 Nita et.al. This is an open access article licensed under the Creative Commons Attribution-NonCommercial-NoDerivs License (http://creativecommons.org/licenses/by-nc-nd/3.0/).

\title{
Niteni, Niroake, Nambahi (3N) Concept in the Learning of Dance in Elementary School
}

\author{
Cicilia Ika Rahayu Nita ${ }^{1}$ \\ Muhammad Jazuli ${ }^{2}$ \\ Totok Sumaryanto F. ${ }^{2}$ \\ Suminto A. Sayuti ${ }^{3}$ \\ ${ }^{1}$ Education of Art Department of Postgraduate Program, \\ Semarang State University \\ ${ }^{2}$ Educations of Dramatic Art, Dance, and Music \\ Department of Postgraduate Program, \\ Semarang State University \\ ${ }^{3}$ Indonesian Language Departments, \\ Yogyakarta State University
}

Doi: 10.2478/mjss-2018-0106

Abstract

Art education at elementary school can serve as the basis of education in shaping the spirit and personality of noble character. At the elementary school level, brain development of children experiences a very fast and real growth. Elementary school is seen as the right agent in the formation of character values because the development of children's brain webs is faster than adult's. The implication of modern education can reduce the values of character, as modern education is preferred to cognitive achievement. Approaches that use local wisdom will be more easily understood by educators. One of the concepts initiated by Indonesian educational leaders, Ki Hajar Dewantara, that is Niteni, Nirokake, Nambahi $(3 N)$ is more easily understood by educators because the concept includes local wisdom values. The purpose of this research is to describe $3 \mathrm{~N}$ in the learning of dance in elementary school. The study implemented qualitative descriptive method with the aim to reveal facts, circumstances, variables, and phenomena. This study presents the data based on the results of observation, interviews, and documentation. The techniques included data collection, data display, data reduction, and conclusion/verification. The results showed that the learning of dance in elementary school conveys $3 \mathrm{~N}$. In addition, teacher's experience can influence students' learning outcomes and creativity. $3 \mathrm{~N}$ encompasses $\mathrm{N1}, \mathrm{N} 2$, and $\mathrm{N} 3$. If the $3 \mathrm{~N}$ stage is not done in accordance with the flow, it will have an effect on the achievement of the learning objectives. This research is still limited to the scope of $3 \mathrm{~N}$ concept study in the learning of dance in elementary school. Therefore, it is expected that the scope of further research can be developed in other science.

Keywords: Niteni, Niroake, Nambahi, the Learning of Dance

\section{Introduction}

The development of the quality of education in Indonesia is still in an optimum improvement effort. The quality of educational outcomes is inseparable from the quality of the learning process. The quality of learning can be seen in the intensity of teacher's teaching behavior, student learning process, materials, media, and learning atmosphere that can produce process and learning outcomes optimally. This is in line with the Indonesian government's efforts to improve the quality of education. Indonesia seeks to launch four pillars of education both for the present and the future. 
The four pillars are learning to know, learning to do, learning to be, and learning to live together. The four pillars of education become mission and responsibility for education. It can be said that one's insight can be more open about knowledge, positive values, others, and the various dynamics of change that occurs (Aunurrahman, 2016: 6-8). Referring to the meaning of meaningful education empowering man, man can think creatively and independently to improve himself and society (Tilaar, 2000: 21). Some of these opinions have been applied in the curriculum 2013 which contains character education on the improvement and balance between soft skills and hard skills that include aspects of attitude, skills, and knowledge competence (Hidayat, 2013: 127) .This has been applied in the form of thematic learning because thematic learning can accommodate various skills, both hard skills and soft skills.

Dance education has a very important role in the development of individual self. The ability to think logically and the ability to develop the potential of self is continuously explored and developed based on the talent and creativity of learners. Dance education also instills a beneficial influence of creative dancing activities on the formation of student personality, not to create dances for performances (Depdikbud, 1999: 180). "...the art of dance not only develops the cognitive and affective aspects but also the psychomotor aspect that can form the level of intelligence and skill in a movement" (Ratih, 2015: 1-2). From this view, it can be understood that dance education has a role in the personal formation of learners to be more harmonious by paying attention to the development of children in achieving multi-intelligence.

The learning of dance trains not only motor aspects, but also cognitive aspects of children. One of them can be seen from how children imitate the movement and memorize dance movements. The learning of dance can also train children's intelligence in recalling and memorizing. According Mulyani (2016: 92), in the implementation process, the learning of dance is a stimulus for children in training cognitive development.

Education of dance in elementary school is contained in intracurricular and extracurricular activities. Intracurricular activities include the activity of teacher and student, in which the activity of teacher, said Suprihatiningrum (2016: 124), includes preliminary activities, core activities, and closing activities. On the other hand, activity of students is listening, seeing, imitating, and doing. Students' learning activity, according to Ki Hadjar Dewantara, is illustrated in the $3 \mathrm{~N}$ concept, Niteni, Niroake, Nambahake. This concept is not (yet) found in direct writings of Ki Hadjar Dewantara, but some writers and bureaucrats reveal the principle of $3 \mathrm{~N}$. Kusmayanto (cited in Suroso, 2011: 51) states that Ki Hadjar Dewantara left us the ultimate science, namely 3N: Niteni, Niroake, and Nambahake. This concept can be viewed as a learning theory.

The above description becomes the basis of the researchers' interest to examine this issue through a scientific research with the focus of the problem: "How is the learning of $3 \mathrm{~N}$-based dance applied in elementary school?

\section{Literary Review}

Ki Hadjar Dewantara often contributes his thoughts to education in Indonesia in the form of principles, learning theory, methods and so on. One of them is the concept of Niteni, Niroake, Nambahake. The term is not (yet) found in the direct writings of Ki Hadjar Dewantara, but Kusmayanto (cited in Suroso, 2011: 51) states that Ki Hadjar Dewantara bequeaths us the ultimate science, namely 3N: Niteni, Niroake, and Nambahake.

Niteni means paying attention, observing, or listening. In this case students pay close attention to observe, read, or listen carefully, and feel with their senses. Niroake means mimicking. Students mimic and do something similar to thing that is observed. Nambahake means students try to add, adjust, and innovate. Based on the above opinion, it can be understood that $3 \mathrm{~N}$ concept proposed by Ki Hadjar Dewantara contains a variety of activities applied in the classroom to achieve learning objectives.

Niteni means the process of searching and discovering the meaning (nature, characteristics, procedure, truth) of an object of observation through the senses (Suroso, 2011: 52-53). Observing is a concept that is always used in the implementation of learning at various levels of education. Particularly in the implementation of curriculum 2013, observing is a mandatory component of the 
learning process. According to Bandura (cited in Gunarsa, 2006: 184), in social situations it turns out that people can learn faster by observing or seeing the behavior of others. Bandura (cited in Gunarsa, 2006: 186-187) suggested four components in the learning process through observation:

(1) noticing, before imitating, people pay attention to the model to be imitated; (2) recalling, after noticing and observing a model, at other times children exhibit the same behavior as the model; (3) reproducing motor motion, in order to reproduce the behavior appropriately, one must be able to demonstrate motor skills; (4) Deuteronomy-reinforcement and motivation, the observed and cautious results of a model will be shown or reproduced in real behavior based on the will or motivation. The willingness to do reinforcement depends on personal circumstances and encouragement.

From the exposure of opinion above, it can be understood that niteni is the process of recognizing and finding the meaning of an object that requires sensitivity of students in observing an object. Similarly, the psychological aspects of students play an important role to connect the perceptions that exist in the mind with objects that are observed.

Ki Hadjar Dewantara in Suroso (2011: 56) argues that a child has a desire to always imitate all that interest him. Niroake or imitating is very useful because it has the nature of educating self through orientation and experience, although with a fantasy (Suroso, 2011: 56). Bandura (cited in Gunarsa, 2006: 186) explained that before doing imitation, people should pay attention to the model to be imitated. In other words, imitating is the next process of observing the model to be imitated. Bandura's observations are confirmed by linking new experiences with prior experience or repeating them (Susanto, 2015: 98). Based on the explanation, in imitating, students need sensitivity of the five senses in order to imitate the discourse or object that has been observed. In addition, students must think and connect the discourse or object to be imitated so as not to deviate with the discourse or original object.

Nambahake, translated as adding or developing, is the advanced process of niroake. In this process, there is a creative and innovative process. Ki Hadjar Dewatara (cited in Suroso, 2011: 58) stated, "We do not imitate, but cultivate". The concept of nambahake is closely related to creativity. The term creativity itself has a lot of understanding depending on the way a person views it. Creativity is the ability of a person to create something new, both in the form of ideas and real work, which is relatively different from what has existed previously (Susanto, 2015: 99) Susanto (2015: $115-117)$ stated that various steps are defined in the creative process, that are:

a) Stimulus. The initial stimulus is driven by the awareness that a problem must be solved or an unclear feeling that there is an idea that is not fully captured or realized. Often this situation is triggered by a challenge to the students' thinking given by the teacher.

b) Exploration. Students are helped to look at the alternatives before making a decision. Students should be able to investigate further and see what they need.

c) Planning. The next stage is opening various plans or strategies for problem solving. From the various plans that are made, some of the most appropriate plans for solutions can be taken.

d) Activity. The creative process begins with an idea or set of ideas. Teachers need to allow the students to realize their creative thinking into action. In other words, after the planning is done, the activity or the implementation of more determined plans is conducted.

e) Review. Students need to evaluate and review the work. Students can be trained to use judgment and their imagination to evaluate.

\section{Methodology}

The research implemented descriptive qualitative method. The subject is the teacher and students of low grade elementary school in Malang. The research was conducted in the elementary school in Malang. This research focused on preliminary activities, core activities, and closing activities. Primary data sources of this study were the results of teacher and student interviews and the results of teacher and student observations. Secondary data sources included documentation in the form of photos and video. Data collection procedures used in this study was observation, interview and documentation. Data validity technique in the research is the criterion of credibility with triangulation. Data analysis 
technique used interactive data analysis from Miles \& Huberman that is data reduction, data presentation, and conclusion and verification. The illustration can be seen in Figure 1.

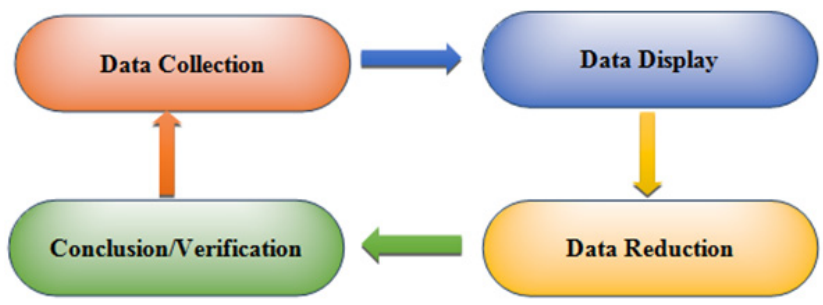

Figure 1. Miles \& Huberman's interactive data model hierarchy

\section{Results and Discussion}

\subsection{Results}

The result showed that the learning of dance in elementary school covers teacher and student activities. Teacher activities include preliminary activities, core activities, and closing activities. In the preliminary activities, the teacher performs several stages including apperception, conveying the learning objectives or basic competencies to be achieved, conveying material coverage and motivating. Teacher's preliminary activities occasionally use movements that contain elements of dance, for example in providing examples in accordance with the theme being taught.

The core activities include exploration, elaboration, and confirmation. At this stage, the teacher presents the material using the media in the form of video, pictures, and observing the environment outside the classroom as the object of observation. Students are guided by the teacher to observe the object, the students pay attention to the object of observation. Students are seen performing motion following the observed object. Students show motor motion by performing the motion based on the observed object. Teachers always provide motivation for students to be more serious in following the learning process. Furthermore, the teacher guides students to simulate a movement that has been exemplified by the teacher or to imitate motion based on the observed object. The teacher guides the students in the process of mimicking; the teacher also lets the students to mimic their own movements without being directed by the teacher.

Teachers provide the task of making simple dance moves to improve the creativity of students in the learning of dance. Assignment is used as a stimulus to student's creativity in completing the task given. Teachers provide opportunities for students to choose the movement according to the theme and creativity based on student experience, object observation, video, and image media. The teacher guides the students to create a dance arrangement design that can then be drawn to some of the most appropriate designs as a work of dance. This process is done by students through group discussion. Furthermore, teachers guide students to convey their ideas that are designed into the motion of dance. Students try with group members to demonstrate their work in front of the class for review by the teacher. Teachers invite students to jointly give appreciation and input to the group that has displayed the work of his dance.

Closing activities include teacher activities with students concluding the learning material. Further, teachers reflect on activities that have been implemented deliver the lesson plans for the next meeting.

\subsection{Discussion}

Bandura (cited in Gunarsa, 2006: 184) suggested that the observing stage involves the process of noticing, recalling, reproducing motor motion, and motivation. The process of noticing is seen when students make observations of the object, students pay attention to the object of observation. The recalling process is visible when the students do motion following the observed 
object. The process of reproducing motor motion is done by showing motor movement to the object of observation. Motivation is given by the teacher so that students more seriously in following the next process. The observing stages can be shown in Table 1.

Table 1. Niteni Stage (Observing)

\begin{tabular}{|c|c|c|}
\hline & Process & Description \\
\hline \multirow{4}{*}{$\begin{array}{l}\text { Niteni } \\
\text { (observing) }\end{array}$} & Noticing & Students observe the object. \\
\hline & Recalling & Students do motion following the observed object. \\
\hline & Reproducing motor motion & Students show motor motion to the object of observation. \\
\hline & Motivation & $\begin{array}{l}\text { Teachers motivate students to be more earnest in following } \\
\text { the next process. }\end{array}$ \\
\hline
\end{tabular}

Plato suggested that mimicking is a process of mimicking near its original form (mimesia) (Teew, 1984: 220). Niroake stage (mimicking) is a continuation stage of the observing stage. Students mimic the dance movement that has been exemplified by the teacher or through the observation of the object. Students mimic the dance movement guided by the teacher and on their own initiative. The teacher directs the students in performing the dance moves in accordance with the correct theme and technique. The observing stages can be shown in Table 2.

Table 2. Niroake Stage (Mimicking)

\begin{tabular}{|c|c|c|}
\hline Stage & Process & Description \\
\hline $\begin{array}{l}\text { Niroake } \\
\text { (Mimicking) }\end{array}$ & $\begin{array}{l}\text { Mimicking the example } \\
\text { given by teacher }\end{array}$ & $\begin{array}{l}\text { Students mimic the dance moves that have been } \\
\text { exemplified by teachers. }\end{array}$ \\
\hline & Mimics the observed object & $\begin{array}{l}\text { Students mimic the movement of dance through the } \\
\text { observation of the object. }\end{array}$ \\
\hline
\end{tabular}

Susanto (2015: 115-117) argued that the creative process includes 5 stages entailing the process of stimulus, exploration, planning, activity, and review. The stimulus process is seen when the teacher gives the task to the students that is making a simple dance movement based on the theme studied. Assignment is used as a stimulus to students to stimulate the ability of creativity in completing the task given. The exploration process is seen when the teacher provides the opportunity for students to choose the movement according to the theme and creativity based on students' experience, object of observation, video, and image media. The planning process is a process whereby the students make the design of dance arrangement which can then be taken some of the most appropriate designs as a work of dance. This process is done by discussing students with group members. The process of activity is where students convey ideas into dance moves. Students try with group members to demonstrate their work in front of the class for review by the teacher. The review process is seen when the teacher invites students to jointly give appreciation and suggestion to the group that has displayed the work of his dance. The observing stage can be shown in table 3 .

Table 3. Nambahi Stage (Adding)

\begin{tabular}{|c|c|c|}
\hline Stage & Process & Description \\
\hline \multirow[t]{5}{*}{$\begin{array}{l}\text { Nambahi } \\
\text { (Adding) }\end{array}$} & Stimulus & $\begin{array}{l}\text { Teacher gives the task to the students to make a simple dance } \\
\text { movement. }\end{array}$ \\
\hline & Exploration & $\begin{array}{l}\text { Teacher provides an opportunity for students to choose the movement } \\
\text { according to the theme and creativity. }\end{array}$ \\
\hline & Planning & Students create a dance movement design. \\
\hline & Activity & Students demonstrate the work of dance in front of the class. \\
\hline & Review & Teacher and students appreciate the work. \\
\hline
\end{tabular}

$3 \mathrm{~N}$ stages, according to Ki Hadjar Dewantara, in the learning of dance in elementary school include Niteni, Niroake, and Nambahi shown in Figure 2. 


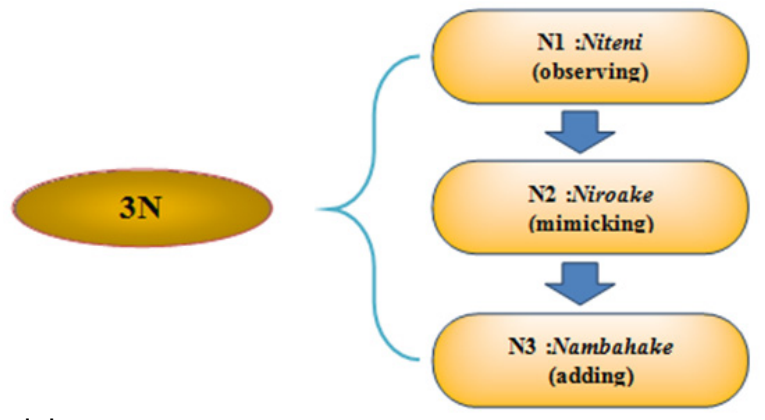

Figure 2. Stage 3N Model

Figure 2 shows that the stages in the $3 \mathrm{~N}$ model based on the concept conveyed by Ki Hadjar Dewantara and supported by other learning theories must be in accordance with the flow of N1, N2, and N3. If the $3 \mathrm{~N}$ stage is not done in accordance with the flow, it will affect the achievement of learning objectives.

\section{Conclusion}

The process of the learning of dance in elementary school involves the activities of teachers and students. Teachers emphasize more on learning activities that are preliminary activities, core activity, and closing activities. In these activities, the teacher teaches the art of dance by using the method and the media in which there is the creativity of the teacher. Students emphasize the activity of listening, seeing, imitating, and doing. Based on the achievement of $3 \mathrm{~N}$ (Niteni, Nirokake, Nambahake), it is obtained the dance learning model implementing the concept of $3 \mathrm{~N}$. Teachers 'experience can affect student learning outcomes and creativity. $3 \mathrm{~N}$ phases include N1, N2, and N3. If $3 \mathrm{~N}$ stages are not done in accordance with the flow, it will influence the achievement of learning objectives. This research is still limited to the scope of $3 \mathrm{~N}$ concept study in the learning of dance in elementary school, it is expected that further research can be developed on the scope of study of $3 \mathrm{~N}$ model development in other sciences.

\section{References}

Aunurrahman. (2016). Belajar dan Pembelajaran. Bandung: Alfabeta

Creswell, J. W. (2013). Research Design, Qualitative Approach, Quantitative and Mixed, Translated by Achamad Fawaid. Yogyakarta: Pustaka Pelajar.

Creswell, J. W. (2005). Educational Reseach, Planing, Conducting, and Evaluating, Quantitative and Qualitative Research. New jersey: Upper Saddle River.

Depdikbud. (1999). Konsep pendidikan kesenian, panduan teknis sebagai pelengkap penataran pendidikan kesenian bagi guru taman kanak-kanak dan guru SD di DKI Jakarta. Jakarta: Depdikbud.

Gunarsa, S. D. (2006). Dasar dan Teori Perkembangan Anak (Editorial staff BPK Gunung Mulia Ed.). Jakarta: PT BPK Gunung Mulia

Hidayat. (2013). Pengembangan Kurikulum Baru. Bandung: Remaja Rosdakarya.

Mulyani, N. (2016). Pendidikan Seni Tari Anak Usia Dini. Yogyakarta: Penerbit Gava Media

Teew, A. (1984). Sastra dan IImu Sastra. Jakarta: Dunia Pustaka Jaya

Susanto, A. (2015). Teori Belajar Pembelajaran di Sekolah Dasar. Jakarta: Prenadamedia Grup

Suprihatiningrum, J. (2016). Strategi Pembelajaran (Teori dan Aplikasi). Yogyakarta: Ar-Ruzz Media

Suroso. (2011). Pemikiran Ki Hadjar Dewantara Tentang Belajar dan Pembelajaran. (online),(http://repository.library.uksw.edu/bitstream/handle/12345678/3178/ART_Suroso_Pemikiran\%20K i\%Hadjar full\%20text.pdf.?sequence=2), Accessed December 2, 2016.

Ratih, A. G. (2015). Penerapan Pendekatan Kritik Holistik dalam Pembelajaran Apresiasi Seni Tari Nusantara Pada Kelas VIIIA di SMPN 2 Pakisaji Kabupaten Malang. Unpublished thesis. Malang: Faculty of Letters State University of Malang.

Tilaar. (2000). Paradigma Baru Pendidikan Nasional. Jakarta: Rineka Cipta. 